\title{
Występowanie i znaczenie terminu „róg" w Biblii
}

\author{
ks. Roman Bogacz
}

Uniwersytet Papieski Jana Pawła II w Krakowie

roman.bogacz@upjp2.edu.pl (D) https://orcid.org/0000-0002-9443-6571

Termin „róg” (w języku hebrajskim: קִרֶ) występuje w Biblii Hebrajskiej 79 razy w 72 wersetach. Natomiast termin grecki képaৎ występuje w Septuagincie 133 razy w 114 wersetach. Z tego wynika, że w niektórych wersetach występuje kilkukrotnie. Łatwo też zauważyć, że termin grecki został użyty o 54 razy więcej niż termin hebrajski. W Nowym Testamencie termin ten występuje 11 razy, i to zaledwie w dwóch księgach. Jeden raz w Ewangelii według św. Łukasza $(1,69)$ oraz 10 razy w Apokalipsie św. Jana, gdzie został użyty na określenie rogów Baranka, ołtarza i różnych apokaliptycznych bestii (Ap 5, 6; 9, 13; 12, 3; 13, 1; $13,1 ; 13,11 ; 17,3 ; 17,7 ; 17,12 ; 17,16)$.

Termin róg w Biblii przyjmuje wiele znaczeń. Często ma znaczenie dosłowne, ale w wielu miejscach przybiera znaczenie przenośne. Wtedy też nabiera znaczenia teologicznego. Chcąc dokładniej stwierdzić, w którym znaczeniu termin został użyty w danym tekście, trzeba dokonać analizy tego tekstu. W niniejszym artykule został zaprezentowany przegląd różnych znaczeń analizowanego terminu, co może być inspiracją do dalszych badań.

\section{Róg zwierzęcia}

O rogach zwierzęcia mówi się w Biblii albo w znaczeniu dosłownym, albo w przenośnym. Ilekroć jest mowa o rogach zwierzęcych, wówczas język hebrajski stosuje liczbę podwójną. W takiej formie termin קַרְנַּ, 
קְרָנֵים (qarnayim, qerānayim) występuje w Starym Testamencie 16 razy (Botterweck \& Ringgren, 2004, s. 170).

Po raz pierwszy o rogach zwierzęcia (baranka) jest wspomniane w Księdze Rodzaju w związku z ofiarą Abrahama. W tym samym momencie, w którym Abraham miał już zabić swego syna Izaaka, aby złożyć go w ofierze, „obejrzawszy się poza siebie, spostrzegł barana uwikłanego rogami w zaroślach. Poszedł więc, wziął barana i złożył w ofierze całopalnej zamiast swego syna” (Rdz 22, 13). Interesujące $\mathrm{w}$ tym opisie, tak bardzo lakonicznym i nie zawierającym zbyt wiele szczegółów, jest zamieszczenie informacji, że baranek zaplątał się rogami w zarośla. Stanisław Łach (1962, s. 395) w komentarzu do tego tekstu wyjaśnia, że zwierzę to mogło tam być już wcześniej zaplątane i nie należy dopatrywać się w tym wydarzeniu jakiejś szczególnej Bożej interwencji. Abraham był tak zajęty przygotowaniem do złożenia ofiary, że nie zauważył zwierzęcia, które mogło tam przybyć wcześniej z większym stadem i zaplątawszy się, pozostać.

Innym tekstem w przeprowadzanej analizie jest werset z Pwt 33, 17. Termin róg odnosi się tu do byka, ale użyty jest metaforycznie w odniesieniu do pokolenia Judy. Jest to fragment błogosławieństwa Mojżesza wypowiedzianego tuż przed jego śmiercią przed wejściem do Ziemi Obiecanej. Mojżesz wypowiada błogosławieństwa nad poszczególnymi pokoleniami Izraela. Kierując błogosławieństwo do pokolenia Józefa, używa określenia „byk”. Stwierdza, że jego moc jest niezwykle silna, ponieważ wyróżnia się dwoma rogami które są „rogami bawołu”. Ta moc może wynikać z wyjątkowej pozycji Józefa jako oblubieńca Boga ${ }^{1}$, zaś dwa rogi mogą odnosić się do pokoleń Efraima i Manassesa. Przy czym w subtelny sposób podkreślona jest różnica pomiędzy tymi pokoleniami. Manassesowi przypisuje się tysiące, a Efraimowi - dziesiątki tysięcy. W tym rozróżnieniu można dostrzec dominację Efraima nad Manassesem.

1 Tekst jest trudny do interpretacji, gdyż Tekst Masorecki podparty tekstem z Qumran (4QDeuth) dodaje przyrostek zaimkowy „jego” byka. Czy Józef jest bykiem Boga, czy posiada jego moc? Trudno znaleźć jednoznaczną interpretację tego tekstu (por. Nelson, 2002, s. 391). 
Symbolika bawoła jako dzikiego byka o niezwykłej sile bierze się stąd, że bawół należy do największych i najsilniejszych zwierząt, na które polowali ludzie z kręgu kultury biblijnej Starego Testamentu. Przywołanie go w obrazach biblijnych zostało użyte dla podkreślenia niezwykłej siły i dostojeństwa, czasem też brutalności. Podobnie obraz bawoła unoszącego rogi oznacza zwycięstwo (1 Sm 2, 1. 10; Ps 92, 11).

Znaczne trudności przysparza tekst Septuaginty, gdzie w miejsce dzi-

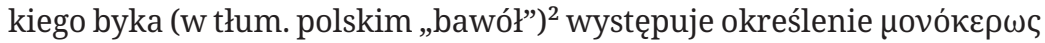
- ,jednorożec”. Popowski w tłumaczeniu Septuaginty użył określenia „antylopa”.

Jednorożec to mitologiczne zwierzę. Opisy przedstawiają je jako podobne do konia lub osła. Posiada białą sierść, niebieskie oczy, a z jego czoła wyrasta długi spiczasty róg. Według starożytnych relacji bardzo trudno było go spotkać, ponieważ charakteryzował się niezwykłą czujnością. Jeśli z oddali wyczuł człowieka, natychmiast uciekał. Posiadał też ogromną siłę i wydawał z siebie przeraźliwy ryk. Według podań z daleka wyczuwał dziewicę. Wtedy przybiegał do niej i kładł róg na jej kolanach. Dlatego można spotkać w sztuce przedstawienia sceny zwiastowania z jednorożcem trzymającym na kolanach Maryi róg33. Ojcowie Kościoła (Ambroży, Hieronim, Kasiodor) porównują Chrystusa do jednorożca. Często też róg jednorożca stawał się w komentarzach egzegetów figurą krzyża (por. Kobielus, 2002, s. 124-130).

\section{Rogi ołtarza}

Użycie terminu „róg” w liczbie mnogiej odnosi się do rogów ołtarza. Dotyczy to zarówno ołtarza przenośnego w Namiocie, jak i do ołtarza kamiennego zbudowanego w Świątyni Salomona, a potem w odbudowanej Świątyni po niewoli babilońskiej oraz przebudowanej przez

2 Biblia Tysiąclecia tłumaczy przez bawół, podobnie Biblia Ekumeniczna, jak też Biblia Paulistów. Natomiast tłumaczenie Septuaginty dokonane przez Popowskiego w tym miejscu zamiast „jednorożec” używa określenia „antylopa”.

3 Takie przedstawienie sceny zwiastowania można spotkać między innymi w Muzeum Narodowym w Warszawie w pentaptyku Mistrza z Wrocławia (XV wiek). 
Heroda. To samo określenie w liczbie mnogiej zastosowano do opisania rogów ołtarza kadzielnego.

\subsection{Rogi ołtarza całopaleń}

Miejsce kultu Boga Jahwe zostało szczegółowo opisane w Pięcioksięgu Mojżesza. W Wj 27, 1-8 został zawarty opis, w którym określono, jak winien być zbudowany ołtarz umieszczony na dziedzińcu Przybytku Pańskiego. Wj 27, 2 podaje informację, że ołtarz winien być zaopatrzo-

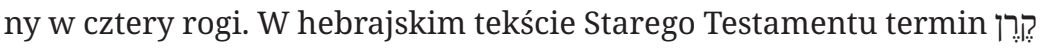
(keren) występuje 76 razy, z czego 32 razy występuje w liczbie mnogiej. Wtedy właśnie odnosi się do rogów ołtarza. Niektórzy egzegeci uważają, że te rogi ołtarza nawiązują do מַצֵ (masseboth) ${ }^{4}$, które umieszczano coraz bliżej ołtarza, a w końcu umieszczono je na jego rogach, dlatego też symbolizują Bożą obecność (por. Galling, 2005, s. 59; Gressmann, 1908, s. 28). Rogi ołtarza całopaleń miały być pokryte brązem, natomiast rogi ołtarza kadzenia były pokryte złotem.

Ołtarz całopaleń w przenośnej świątyni był zbudowany z drewna akacjowego obłożonego brązem. Można przypuszczać, że ta drewniana skrzynia została wypełniona piaskiem i kamieniami. Jednak nic na ten temat w tekście Wj 27, 1-8 nie zaznaczono (por. Lemański, 2008, s. 552). Natomiast ołtarz w Świątyni Jerozolimskiej winien być zbudowany z nieciosanych kamieni. Określono, że należy go zbudować z dwunastu kamieni, stosownie do liczby pokoleń Izraela. Aby mógł być on prawdziwie ołtarzem ku czci Jahwe, musiał mieć cztery rogi wznoszące się ku górze. Te rogi są niejako zakotwiczeniem ołtarza w Bogu. Dzięki temu zakotwiczeniu ołtarz posiada szczególną moc, która uświęca składaną ofiarę. Skierowanie rogów ołtarza ku górze symbolizuje też skierowanie dymu ku niebu.

Przepis zawarty w Wj 29, 12 (por. Kpł 4, 25) nakazywał obrzęd oczyszczenia ołtarza polegający na pomazaniu rogów ołtarza krwią.

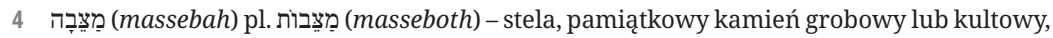
zwykle jest nieociosany, ustawiony pionowo. Dla upamiętnienia ważnego wydarzenia pokrywano go inskrypcjami (por. Köhler et al., 2008, s. 583-584). 
Tak jak człowiek potrzebuje oczyszczenia i uświęcenia, które dokonywało się przez rytualne obmycia oraz pokropienie krwią, podobnie też oczyszczenia potrzebował ołtarz. Na nim bowiem ludzie składali ofiary. Poprzez te ofiary nie tylko oddawali cześć Bogu, ale też jednoczyli się z Nim. Pomazanie krwią jest obrzędem oczyszczającym i uświęcającym ołtarz. Dla świątyni ołtarz ma kluczowe znaczenie. Jest on znakiem Bożej obecności.

Rogi ołtarza miały też znaczenie miejsca ucieczki. Przestępca, który wykroczył przeciwko prawu albo przeciwko władcy, mógł uzyskać ułaskawienie, chwytając się za rogi ołtarza. Przestępcą mógł stać się nawet ktoś z najbliższych krewnych króla, zwłaszcza gdy posiadał on wiele żon i dużą liczbę dzieci ubiegających się o różne przywileje. Wielożeństwo praktykowane w Izraelu jeszcze w czasach królewskich stawało się przyczyną różnych rozgrywek pomiędzy synami króla. Adoniasz, syn Dawida i jego żony Chaggity, widząc, że król Dawid jest już stary i niedołężny, postanowił zostać królem. Ponieważ Dawid jeszcze żył, czyn ten był jawnym spiskiem przeciw królowi. Prorok Natan przyszedł do króla i oznajmił mu co zaszło: Adoniasz obwołał siebie królem. Wtedy Dawid nakazał namaścić Salomona na króla. Kiedy ludność oddawała hołd nowemu królowi Salomonowi, wówczas Adoniasz zrozumiał, że dni jego są policzone, udał się więc do Namiotu i uchwycił się rogu ołtarza (por. $1 \mathrm{Krl}$ 1, 50). Dzięki temu nie zginął jako spiskowiec. Uchwycenie się rogów ołtarza było dla niego zbawieniem. Stąd można wprost powiedzieć, że gest uchwycenia rogów ołtarza ma zbawczy wymiar.

W podobnej sytuacji znalazł się Joab, syn Serui (por. 1 Krl 2, 28). Tekst hebrajski zaznacza, że popierał Adoniasza, który pretendował do tronu, a nie popierał Absaloma. Septuaginta w miejscu Absaloma wymienia Salomona. Tak więc Salomon, chcąc utwierdzić swoją władzę królewską, musiał pozbyć się swoich wrogów. Widząc zagrożenie swego życia, Joab udał się do Namiotu Pańskiego i uchwycił się rogów ołtarza. Okazuje się jednak, że Salomon był doskonałym znawcą prawa. Uchwycenie się rogów ołtarza dawało prawo azylu temu, kto nieumyślnie zadał śmierć drugiemu człowiekowi (Wj 21, 14). Salomon wyjaśnia, że Joab bez wiedzy Dawida zabił dwóch ważnych dowódców wojsk króla: Abnera, syna Nera, wodza wojsk izraelskich, oraz Amasę, syna Jetera, wodza wojsk 
judzkich (por. $1 \mathrm{Krl}$ 2, 32)5. Rozmyślne zabójstwo z premedytacją nie mogło dać prawa łaski, nawet wtedy, gdy ktoś uchwycił się rogów ołtarza. Dlatego Salomon kazał Joaba zabić nawet przy ołtarzu, jeśliby nie chciał opuścić Świętego Namiotu (por. Łach, 2007, s. 154).

\subsection{Rogi ołtarza kadzenia}

Podobnie jak ołtarz całopaleń, także ołtarz kadzenia na czterech narożnikach był zaopatrzony w rogi, które wznosiły się ku górze. Miały być one wykonane z tego samego kawałka drewna co ołtarz. Były podobnie jak ołtarz pokryte złotem (por. Wj 30, 2-3). W czasie konsekracji ołtarza kadzenia, a także w Dzień Przebłagania rogi te były namaszczane krwią zwierząt ofiarnych (Wj 30, 10; por. Lemański, 2008, s. 585). Ta konsekracja sprawiała, że ołtarz posiadał nadzwyczajną świętość (Wj 29, 36-37; 30, 10; Kpł 4, 7; 8, 15; 16, 18-19). Człowiek uciekający przed zemstą sięgał po tę świętość, szukając azylu, chwytał za owe rogi (por. Tronina, 2006, s. 104). Wtedy pozostawał pod specjalną ochroną Boga.

Roland de Vaux (2004, s. 426-427) stwierdza, że trudno wyjaśnić, jakie jest znaczenie tych rogów. Próbuje on odnieść się do mocy zwierząt ofiarnych oraz do czaszki byka znajdowanej przy rzymskich ołtarzach. Bardziej prawdopodobne jest odwołanie do stel, które umieszczano w pobliżu ołtarza. Wydaje się, że ważne jest ich ukierunkowanie ku górze, co oznacza skierowanie dymu ofiarnego w stronę nieba, gdzie Bóg zasiada na tronie. W ten sposób dym zanosił ofiarę do Boga przebywającego w niebie. Dym kadzidła wznoszący się ku niebu zanosił też do Boga modlitwy odmawiane w Przybytku. Bóg wysłuchiwał modlitw ludu i dawał mu wybawienie z trudnych sytuacji.

5 Ernst Würthwein (1977, s. 7-9) uważa, że wiersze 2 Krl 2, 31-33 są późniejszym dodatkiem. Zaznacza on, że działania Salomona zmierzające do utwierdzenia swej władzy położyły się cieniem na początkowych etapach królowania. Dlatego późniejszy redaktor, chcąc podkreślić doskonałą znajomość prawa przez Salomona uzasadnił jego decyzje, podkreślając, że prawo azylu nie obejmuje zbrodniarzy zabijających z premedytacją. 


\section{Róg zbawienia}

W przeprowadzanej analizie na szczególną uwagę zasługują cztery teksty, w których róg użyty jest w nieco innym kontekście. Dwa z nich mówią o rogu zbawienia, jedno o rogu mesjasza, a jedno o moim rogu. Najpierw warto pochylić się nad 1 Sm 2, 1 i 10, gdzie jest mowa o rogu Mesjasza.

Termin „róg” występuje w pierwszym i ostatnim wersecie pieśni Anny, matki Samuela (1 Sm 2, 1. 10). Tworzy on inkluzję obejmującą całą pieśń, którą wyśpiewała po urodzeniu syna i oddaniu go na wyłączną służbę dla Jahwe w Przybytku Pańskim w Szilo. Przyprowadziła ze sobą trzyletniego cielca, przyniosła efę mąki oraz bukłak wina (por. 1 Sm 1, 24). Po złożeniu ofiary wyśpiewała Bogu pieśń. Anna poczuła się wyjątkowo wybrana przez Boga. Dzięki temu wybraniu jej męski potomek zyskał wielką moc Boga. Dosłowne tłumaczenie wersetu 1 Sm 2, 1 brzmi: „mój róg został wywyższony w moim Bogu”. Termin „róg” został tu użyty jako synonim syna, męskiego potomka, którym Bóg obdarował Annę. Pieśń prorocka wyśpiewana przez Annę prowadzi myśl skierowaną w daleką przyszłość, aż do przyjścia Mesjasza (por. Auld, 2011, s. 38). Dla swego syna wybrała wyjątkowe teoforyczne imię Samuel. Dzięki Bogu wyrósł on na kogoś wyjątkowego. To przez niego zostaje w Narodzie Wybranym założona dynastia królewska. Szczególnym ukoronowaniem tej dynastii będzie Mesjasz Król, potomek Dawida. Kończąc pieśń uwielbienia, Anna wydała okrzyk wyrażający zwycięstwo Jahwe, który osądza krańce ziemi. Ten potężny Jahwe, który grzmi na niebiosach, przekazuje też potęgę królowi i wywyższa „róg” Mesjasza (por. 1 Sm 2, 10; por. Łach, 1973, s. 117-118).

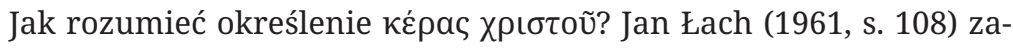
uważa w tym tekście obecną na kartach Starego Testamentu ideę Bogasędziego. Wyrazem tej idei są wojny prowadzone przez Jahwe. Wojny te czasem prowadzi On sam, ale częściej Jego obecność wyrażona jest poprzez wnoszenie Arki Przymierza na pole walki. Innym razem posługuje się on wybranymi ludźmi. W tym miejscu idea Boga-sędziego została połączona z ideą Mesjasza-króla. Wyrażenie „róg namaszczonego” odnosi się do idei namaszczania króla. Wtedy sam róg należy rozumieć 
jako naczynie na olej służący do namaszczania. W takim rozumieniu namaszczenie jest wskazaniem, że ten król otrzymuje od Boga potęgę, którą Stwórca przekazuje swemu pomazańcowi.

Kolejne wystąpienie terminu „róg”, które odnajdujemy w 2 Sm 22, 3, jest o tyle ważne, że użyto go dosłownie tak samo jak w kantyku Zachariasza z Ewangelii św. Łukasza. Jest tu mowa o „rogu zbawienia”. Werset ten pochodzi z pieśni wyśpiewanej przez Dawida. Król wychwala Boga za to, że wielokrotnie wybawiał go z rąk jego wrogów. Bóg staje się dla niego rogiem zbawienia. Podobnie jak róg ołtarza był jedynym wybawieniem dla tych, którzy za swoje występki (grzechy) winni być skazani na śmierć. To Bóg może człowieka wyswobodzić od gwałtu oraz od grzechu (por. Łach, 1973, s. 482-483).

Pieśń Dawida z 2 Sm 22, 1-51 w znacznej mierze pokrywa się z Ps 18 (17). Niektórzy egzegeci uważają, że obydwie pieśni pochodzą od samego Dawida ${ }^{6}$, a inni, że Dawid dał pierwotny zręb pieśni, która trwała w tradycji ustnej i została wpisana w 2 Sm 22, gdzie zupełnie nie łączy się z treścią księgi oraz zapisano ją odrębnie jako Ps 18.

Psalm 18 zaliczany jest do psalmów mesjańskich. Jest on dziękczynieniem króla, który po zwycięskiej wojnie oddaje Bogu chwałę i uwielbia Go swoją modlitwą. Położenie geograficzne Izraela sprawiało, że Naród Wybrany często był wciągany do walki. Stąd też jest mowa o świętych wojnach. Do takiej wojny naród był zwoływany przez granie na rogach (por. de Vaux, 2004, s. 267). Przytaczane w pierwszych wersetach obrazy przywołują na myśl ideę świętej wojny. To Bóg w imieniu króla prowadzi tę walkę. On staje się rogiem zbawienia. Hans-Joachim Kraus (1958, s. 15) w komentarzu do Księgi Psalmów zauważa tu ideę jakiegoś boskiego króla, który przyniesie zbawienie. Można więc w określeniu „róg” dostrzec naczynie na olej służący do namaszczania. Byłaby to zapowiedź nadejścia namaszczonego przez Boga-króla, który doprowadzi do zbawienia i będzie z mocą bronił swego ludu. W dalszych wersetach ta idea zbawienia kieruje się w stronę zbawienia wiecznego (por.

6 O pochodzeniu pieśni od Dawida pisał Albright, 1956, s. 146. Uważa on, że pieśń ta powstała w X wieku przed Chrystusem. Z kolei Otto Eißffeldt (1956, s. 555) wprost przypisuje pełne autorstwo zarówno pieśni Dawida jak i Ps 18 samemu Dawidowi. 
Borowski, 1983, s. 97-98). Dlatego określenie „róg zbawienia” należy analizować z perspektywy Nowego Testamentu.

W Nowym Testamencie określenie „róg zbawienia” pojawia się tylko jeden raz w Łk 1, 69 w tak zwanym kantyku Zachariasza. Został on wyśpiewany w bardzo interesującym kontekście sytuacyjnym. Od momentu spotkania z Archaniołem Gabrielem w Świątyni Jerozolimskiej Zachariasz pozostał głuchoniemy. Nie uwierzył w Boże przesłanie, z tego powodu Bóg dotknął jego słuch i mowę. Nie mógł ani słuchać, ani głosić Bożego orędzia. Jednak, gdy narodził się mu syn i zdecydował się wypełnić wolę Bożą, nadając mu imię Jan, wówczas Bóg przywrócił mu słuch i mowę. Zachariasz jako pierwszy akt wdzięczności wobec Boga wyśpiewał hymn na jego cześć. Było to w ósmym dniu po narodzinach Jana, gdy rodzina przyszła na uroczystości związane z obrzezaniem syna, nadaniem imienia i uznaniem go za własnego syna.

Warto podkreślić, że podczas tych uroczystości była też obecna Maryja. Przyszła do Elżbiety, by pomóc jej w ostatnich dniach przed narodzinami dziecka oraz w pierwszych miesiącach po przyjściu Jana na świat. Maryja była w stanie błogosławionym. Nosiła pod sercem Bożego Syna. W dniu jej przyjścia do Elżbiety została przez nią powitana: „A skądże mi to, że matka mojego Pana (tzn. Boga) przychodzi do mnie” (Łk 1, 43). Czy Zachariasz też wiedział o błogosławionym stanie Maryi? Czy wiedział, kogo ona nosi pod sercem? Tego nie wiemy. Jednak św. Łukasz jako autor Ewangelii tak komponuje kantyk Zachariasza, że cała pierwsza część tej pieśni jest uwielbieniem Boga za dar Mesjasza, a dopiero druga część odnosi się do Jana.

Znacznym wyzwaniem jest rozstrzygnięcie, do kogo odnoszą się słowa: „wzbudził dla nas róg zbawienia”. Hymn ten wyśpiewuje Zachariasz, aby uczcić Boga za dar Jana Chrzciciela. Czy zatem te słowa należy odnosić do Jana, czy raczej do Jezusa?

Kompozycja Kantyku Zachariasza jest niezwykła. Ma on budowę koncentryczną (por. Mickiewicz, 2011, s. 148). W samym centrum jest mowa o przymierzu i przysiędze danej Abrahamowi. Dla naszych rozważań istotne są wersety 69 oraz 77. Pierwszy z nich jest drugim wersetem hymnu, stanowi wprowadzenie do kantyku i skierowany jest do Zbawiciela. Natomiast werset 77 jest drugim wersetem opiewającym 


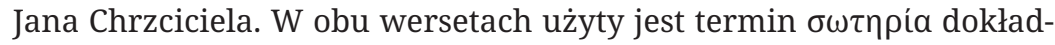
nie w tej samej formie gramatycznej ( $\left.\sigma \omega \tau \eta \operatorname{cí}^{7} \varsigma^{7}\right)$. Idea zbawienia łączy te dwa wersety.

Bardzo interesujące jest powiązanie wersetów 69 i 77. W wersecie 77 nie zostało użyte słowo „róg”. Jednak w podtekście można odczytać ciekawą ideę. Zadaniem Jana jest dać poznać zbawienie ludowi Bożemu. Jak już to zostało wyżej zaznaczone, synoptycy odnoszą do niego słowa Izajasza obwieszczające nadejście Mesjasza. W momencie, gdy przyszedł do niego Jezus, Jan ogłosił: „oto Baranek Boży, który gładzi grzech świata” (J 1, 29. 35). Można więc zrozumieć, że Jan jest dźwiękiem rogu, który ogłasza nadejście świętego czasu zbawienia. Tak jak święta były w judaizmie ogłaszane dźwiękiem rogu, tak Jan ogłosił swoim słowem i posłannictwem, że nadszedł święty czas, w którym dokonuje się zbawienie ludu.

Zagadnienia związane z „rogiem zbawienia” warto opracować szczegółowo w odrębnym artykule, tutaj zostały one jedynie zasygnalizowane.

\section{Róg jako naczynie na oliwę}

Bóg dokonuje wielkich rzeczy w historii zbawienia. Bezpłodną Annę wybrał na matkę Samuela, gdy ona gorąco modliła się przed Bogiem w Szilo, nie wypowiadając na głos słów, ale całe serce zanosząc ku Bogu. Heli widział tylko to, co było dostępne dla jego oczu: Anna poruszała wargami, nie wypowiadając głośno modlitwy. Sądził, że jest pijana i powiedział do niej: ,jak długo będziesz pijana”. Jak długo będzie to jeszcze trwało? (עַד־מָתַי 'ad-mātay; 1 Sm 1, 14). Już czas się wypełnił i Bóg ma swój plan. W tym Bożym planie przewidziane było narodzenie Samuela - męża Bożego, którego zadaniem było ustanowić monarchię w Izraelu, gdzie król ziemski miał spełniać władzę w imieniu Boga. Miały to być rządy teokratyczne. Król-człowiek był pomazańcem Pańskim. Przez niego Jahwe wybawiał swój lud.

7 Rzeczownik, rodzaju żeńskiego liczba pojedyncza w dopełniaczu. 
W taki sam sposób, jak kapłan Heli do Anny, Bóg zwrócił się do Samuela (1 Sm 16, 1): „Jak długo będziesz się smucił z powodu Saula?”. Teraz już nadszedł czas wypełniania historii zbawienia. Bóg dał Samuelowi konkretne wskazanie: „Napełnij róg oliwą i idź: posyłam Cię do Jessego Betlejemity” (1 Sm 16, 1). Zadaniem Samuela jest namaszczenie Dawida na króla celem zapoczątkowania ważnej dynastii, z której wyjdzie zapowiadany Mesjasz-Król. Użycie rogu z oliwą do namaszczenia nowego króla ma na celu ukazanie, że moc tego pomazańca Pańskiego będzie pochodziła od Boga. Dlatego w akcie namaszczania Samuel unosi róg do góry i wylewa oliwę na głowę młodego Dawida. Autor od razu zaznacza, że Duch Boży opanował Dawida (1 Sm 16, 13).

Spełnianie się proroczych zapowiedzi realizowane jest w historii zbawienia z pokolenia na pokolenie. Kiedy już Dawid się zestarzał, wówczas kapłan Sadok wszedł do Namiotu Spotkania i wziął z niego róg oliwy, aby namaścić Salomona na króla nad Izraelem. Dokonał tego przy źródle Gihon (1 Krl 1, 39). Obrzęd namaszczenia Salomona na króla odbył się według przepisanego rytuału. Miał on trzy ważne punkty. Pierwszym z nich była uroczysta procesja do źródła Gihon. Po wstępnych obrzędach w pałacu królewskim posadzono następcę tronu na prywatną oślicę króla Dawida. Był to znak, że ojciec zrzeka się władzy na rzecz syna. Uroczysty orszak wyruszył procesyjnie do źródła żywej źródlanej wody. Źródło Gihon jest położone w dolinie Cedronu na wschód od Miasta Dawida. Kolejnym był obrzęd namaszczenia nowego króla. Dokonano tego obrzędu głęboko w dolinie przy źródle. Trzeba zwrócić uwagę na dwa symbole: róg jako naczynie na oliwę oraz sama oliwa, która została wzięta z miejsca, gdzie mieszkał Bóg Jahwe, czyli z Przybytku Pańskiego. Trzecim punktem był orszak wstępujący w górę do świątyni przy dźwięku rogu, fletów i gromkich okrzykach: „niech żyje król Salomon” (1 Krl 1, 39-40).

\section{Róg jako żyzny pagórek $(\mathrm{Iz} 5,1)$}

Niezwykłe użycie terminu róg występuje w Iz 5, 1. Werset ten rozpoczyna pieśń o miłości Przyjaciela do Jego winnicy. Pieśń ta jest pełna 
symboliki. Przyjacielem, dla którego pieśń została wyśpiewana, jest Bóg Jahwe. Posiadanie winnicy dla Izraelity zawsze oznacza coś bardzo cennego. Ten kawałek pola trzeba było solidnie uprawiać, by wydał słodkie jagody. Można $\mathrm{z}$ nich uzyskać wino, które rozwesela serca ludzi (por. Sdz 9, 13; Ps 104, 15). Nie jest to jakaś winnica, którą się uprawia. Symbolizuje ona Naród Wybrany. Ziemia Obiecana przypominająca uprawną winnicę była symbolem wielkiej szczodrobliwości Bożej względem Izraela. Ta winnica znajduje się w wyjątkowym miej-

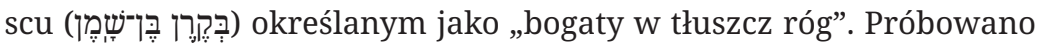
ten fragment tłumaczyć na różne sposoby. Niektórzy rozumieją go jako „spiczasty pagórek” przypominający swym kształtem róg. Ale praktyka nie wskazuje takiego miejsca jako właściwego dla zakładania winnicy. Palestyńska winnica niekoniecznie musi być zbudowana na zboczach nasłonecznionych wzgórz. Biblia Tysiąclecia przełożyła ten zwrot jako „żyzny pagórek”. Może to tłumaczenie jest lepsze, ale też nie oddaje całego sensu zawartego w obrazie rogu.

Trzeba postawić pytanie jak rozumieć całe poetyckie określenie o niezwykłej sile wyrazu: „Przyjaciel mój miał winnicę na rogu obrośniętym tłuszczem” (Iz 5, 1)? Symmach próbuje ten obraz przetłumaczyć w ten sposób, że winnica była położona w rogu ogrodu pośród oliwek. Inni bibliści próbują przełożyć podobnie jak Biblia Tysiąclecia, że winnica była na żyznym pagórku (por. Schwarzenbach, 1954, s. 19). Jeszcze inni, jak Budde i Wildberger, wskazują, że ta winnica wynosiła się ponad widnokrąg. Tadeusz Brzegowy (2010, s. 292-293) podkreśla, że każdy z elementów jest istotny w obrazie, a poeta skumulował ze sobą wszystkie szlachetne rzeczy: winnicę jako cenny ogród będący znakiem Bożego błogosławieństwa, oliwę, która służy czci bogów i ludzi (por. Sdz 9, 9), oraz róg kojarzony z najświętszym elementem ołtarza namaszczanym oliwą i krwią zwierząt ofiarnych.

Cały ten obraz wprowadza niezwykłą treść. Odnosi się do Izraela, którego Bóg wybrał i otoczył opieką jak właściciel troszczy się o winnicę. Wybranie powiązane jest z namaszczeniem i przekazaniem misji. Naród Wybrany miał dawać świadectwo o Bogu Stwórcy kochającym człowieka. W tym Narodzie Bóg objawiał siebie światu i przygotowywał do posłania wyjątkowego Mesjasza, którym po wiekach okazał się Boży Syn. 


\section{Róg jako symbol Bożej mocy (Szofar)}

Boże działanie w dziejach Izraela ma wiele wymiarów. Bóg objawia siebie i przemawia do Mojżesza na Synaju z wielką mocą (Wj 19, 3). Prowadzi naród wybrany przez pustynię, a w końcu realizuje daną obietnicę i wprowadza Izraela do Ziemi Obiecanej. Pierwszym miastem warownym po przekroczeniu Jordanu było Jerycho. Opis zdobycia tego miasta warownego ma charakter nie tyle militarny, ale teologiczny. Przede wszystkim jest to objawienie mocy Bożej. W tekście hebrajskim Księgi Jozuego (Joz 6, 2-25) termin קִרְ (,róg”) występuje w tym opisie tylko jeden raz (Joz 6, 5). W Targumie Aramejskim pojawia się jeszcze w wersecie Joz 6, 13.

W języku hebrajskim istnieje odrębne określenie na oznaczenie trąby wykonanej z rogu, termin ten brzmi שוֹפָר (szofar), język grecki używa

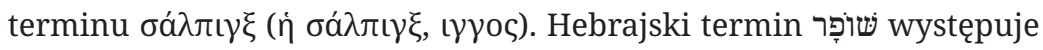
72 razy w Biblii w 63 wersetach. W tekście opisującym zdobycie Jerycha w Joz 6, 1-21 występuje czternastokrotnie, a w wersecie 13 został użyty aż trzykrotnie. W tym wersecie Targum Aramejski zamieszcza wyjaśnienie, że trąby te zostały zrobione z rogów baranich.

Nie sposób omówić wszystkich miejsc występowania terminu szofar w krótkim artykule. Ograniczamy się tylko do opisu zdobycia Jerycha, gdyż w tym miejscu występują zarówno termin „róg” jak i „szofar”.

Michaël N. van der Meer (2009, s. 19-20) zauważa, że tekst grecki (LXX) jest znacznie krótszy od hebrajskiego (MT). W dodatku tekst hebrajski jest zbudowany nieproporcjonalnie. Opis przygotowania zdobycia Jerycha zajmuje dużo więcej miejsca niż opis samej walki, której przebieg to siedmiokrotne okrążenie miasta, wzniesienie okrzyku i zagranie na trąbach, po czym nastąpiło wejście do miasta. Różnice wprowadzone do tekstu hebrajskiego pochodzą z redakcji kapłańskiej. W tekście znajdziemy kilka słów-kluczy, które występują siedem razy. Siedmiu kapłanów okrążało miasto w uroczystej procesji, niosąc w ręku trąby zrobione z rogów baranich, za nimi szli lewici i nieśli Arkę Przymierza jako największy skarb Izraela. Kapłani w siódmym dniu siedmiokrotnie zadęli w szofary (por. van der Meer, 2009, s. 30-31). W tekście tym Szofar występuje 14 razy (czternaście to dwa razy siedem). 
Szofar jest tu symbolem tak wielkiej mocy Bożej, że mury Jerycha tego nie wytrzymują i rozsypują się, otwierając Izraelitom drogę do miasta.

\section{Róg w literaturze apokaliptycznej}

Apokaliptyka posługuje się językiem pełnym obrazów i symboli. W Dn 7, 3-21 oraz 8, 3-22 zaprezentowane są wizje, w których pojawiają się bestie o nadzwyczajnej sile. W wizjach tych opisane są zwierzęta zaopatrzone w rogi, charakteryzujące się bardzo dziwnymi szczegółami. Jedno z nich posiadało aż dziesięć rogów, a wśród nich pojawił się nowy róg zaopatrzony w ludzkie oczy i usta. Wypowiadał on bluźnierstwa (7, 7-8). Bestia ta miała niezwykłą niszczycielską siłę. Posiadała zęby z żelaza i miedziane pazury, którymi miażdżyła wszystko, co napotkała. W kolejnych wizjach pojawił się szarżujący rogami baran i kozioł z jednym rogiem między oczyma, który pokonał barana, a następnie ten róg został złamany i wyrosły cztery kolejne rogi. Wizje te przedstawiają walkę o władzę w imperium Medów i Persów, a następnie w Wielkiej Helladzie. Kozła z jednym rogiem wprost identyfikuje się z Aleksandrem Wielkim, a cztery rogi, które wyrosły po złamaniu tego jednego, to czterech diadochów, którzy objęli władzę po Aleksandrze (por. Botterweck \& Ringgren, 2004, s. 172).

Mitologie Bliskiego Wschodu przedstawiają bóstwa zaopatrzone w rogi, co ma symbolizować ich władzę i potęgę. Egipscy bogowie też posiadali ten atrybut: Ozyrys, Re, Horus, Amon, Izyda, Hathor. Podobnie bogowie Mezopotamscy byli przedstawiani z rogami: Enlil, Marduk Tergal, Szamasz, Sin. W Ugarit boga El nazywa się bykiem. W Starym Testamencie rogi są symbolem siły, wielkiej mocy i zwycięstwa (por. Ps 92, 11; 132, 17; Ez 29, 21). Termin „róg” często łączy się z tematyką królewską. Symbolika rogów ma znaczenie ambiwalentne. Może zarówno odnosić się do dobra, jak i do zła. Przy pomocy rogu może też być wyrażony majestat i potęga Boga (por. Ha 3, 4; 2 Sm 22, 3; Parchem, 2008, s. 455).

W etiopskiej Księdze Henocha rogi zwierząt symbolizują zwycięskie dokonania wojsk machabejskich (HenEt 90, 9). Z kolei Reguła 
Błogosławieństw z Qumran używa terminu róg w błogosławieństwie skierowanym dla księcia zgromadzenia (1QSb). Prorok Zachariasz, pisząc o wielkiej sile wrogich narodów, posługuje się symbolem czterech rogów, aby opisać spustoszenie Izraela, Judy i Jerozolimy (Za 2, 1-4).

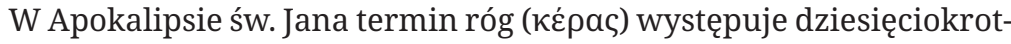
nie: Ap 5, 6; Ap 9, 13; Ap 12, 3; Ap 13, 1; Ap 13, 1; Ap 13, 11; Ap 17, 3; Ap 17, 7; Ap 17, 12; Ap 17, 16. Pierwsze użycie terminu róg w Apokalipsie św. Jana dotyczy siedmiu rogów, które posiada Baranek. W tym wersecie jest też mowa o posiadaniu przez niego siedmiorga oczu. Liczba siedem oznacza pełnię. Tak więc Baranek posiada pełnię mocy (rogi) oraz pełnię wiedzy (oczy są ośrodkami wiedzy). Augustyn Jankowski (1959, s. 170-171) zwraca uwagę, że wizje janowe są intelektualne i nie należy ich sobie wyobrażać.

Pełne grozy wizje Apokalipsy to znaki, które mają doprowadzić ludzi do nawrócenia. Kiedy miało być zrealizowane drugie „biada”, wówczas od rogów ołtarza dał się słyszeć Boży głos. Ten głos jest odpowiedzią Boga na modlitwy Kościoła (Ap 8, 3).

W tej księdze rogi mają też negatywne znaczenie. W Ap 12, 3 przywołany został smok, który ma dziesięć rogów. Występuje on przeciwko Niewieście. Obraz ten został zaczerpnięty z Dn 7, 7, gdzie symbolizuje imperium Seleucydów. W Apokalipsie oznacza on całą zbiorowość potęg wrogich Chrystusowi i jego Kościołowi. W kolejnym obrazie Jan przytacza bestię wyłaniającą się z morza (Ap 13,1), co wyraźnie nawiązuje do snu Daniela i czwartej bestii ukazanej w tej księdze. Pełne wyjaśnienie, kim jest owa Bestia, następuje w Ap 17, gdzie jest mowa o siedmiu pagórkach. Jest to wyraźna aluzja do Rzymu, a kolejne szczegóły nawiązują do jego władców, szczególnie do Nerona. Zaś diademy, o których tu mowa $(13,1)$, nawiązują do rzymskich cezarów, którzy uzurpują sobie prawo Bożego kultu. Podobnie negatywne znaczenie ma termin „róg” użyty w Ap 13, 11, gdzie jest mowa o bestii wyłaniającej się z ziemi, mającej dwa rogi podobne do rogów Baranka. Komentatorzy odczytują ten obraz jako symbol ziemskich fałszywych kultów, które są wytworami ludzi, a nie wynikają z Bożego objawienia (por. Vanni, 2009, s. 138). 


\section{Zakończenie}

„Róg” w Piśmie Świętym ma ambiwalentne znaczenie. W podstawowym, dosłownym sensie oznacza róg zwierzęcia i wyraża jego siłę i moc. Z tego podstawowego znaczenia wypływa jego symbolika.

Tym samym terminem co róg zwierzęcia w Starym Testamencie określa się rogi ołtarza całopaleń i ołtarza kadzenia oznaczające obecność Boga, u którego azyl może znaleźć nawet zabójca i uchwyciwszy się rogów - uzyskać ułaskawienie.

Niektóre teksty używają terminu „róg” w znaczeniu naczynia na oliwę służącą do namaszczenia ludzi wybranych do pełnienia ważnych funkcji w Izraelu. Osoba namaszczona stawała się pomazańcem Pańskim. Mogła wtedy spełniać funkcję króla, kapłana bądź proroka. Funkcje te wypełniała w imieniu Boga Jahwe.

„Róg” może oznaczać też wkroczenie wielkiej Bożej mocy. Tak było w przypadku zdobywania Jerycha, gdy naród głośno zakrzyknął, a kapłani zagrali na rogach. Opis zdobycia murów Jerycha ma znaczenie teologiczne - jest ukazaniem wielkiej mocy Bożej objawiającej się na skutek dęcia w baranie rogi i wzniesienia okrzyku bojowego. Boża moc sprawiła rozsypanie się murów warownego miasta. Obraz procesji i dęcia w rogi ma znaczenie kultyczne. Tekst opisujący zdobycie Jerycha został napisany przez redaktora kapłańskiego.

Istotne znaczenie posiada użycie terminu „róg” w pieśni Anny w 1 Sm 2,1.10. Tworzy on inkluzję obejmującą ten kantyk. Na początku pieśni słowa „róg mój” można odczytać w znaczeniu męskiego potomka Anny - Samuela, zaś na końcu jest mowa o „rogu mesjasza”. To właśnie Samuel namaścił Dawida na Króla, a w sensie prorockim określenie to wybiega myślą ku obiecanemu Mesjaszowi, o którym Zachariasz opowiada przy obrzezaniu Jana Chrzciciela. Wciąż otwartą

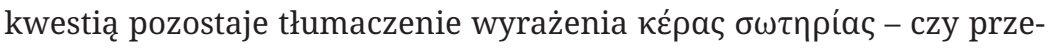
kładać je dosłownie jako „róg zbawienia”, czy raczej jako „moc zbawczą”. Wydaje się, że dosłowne tłumaczenie jest bogatsze w treść i daje głębsze zrozumienie przekazywanych prawd.

Oprócz tych pozytywnych treści omówionych powyżej zdarzają się w Biblii również negatywne konotacje terminu „róg”. W literaturze 
apokaliptycznej termin ten symbolizuje różne złe moce, które występują przeciwko Bogu i człowiekowi. Niektóre wystąpienia terminu „róg” symbolizują walkę władców ziemskich z ludem Bożym, a nawet z samym Bogiem. Apokaliptyka akcentuje jednak, że w końcowej walce zawsze zwycięża Bóg.

\section{Abstrakt}

\section{Występowanie i znaczenie terminu „róg" w Biblii}

„Róg” w Piśmie Świętym w dosłownym sensie oznacza róg zwierzęcia i wyraża jego siłę i moc. Tym samym terminem w Starym Testamencie określa się rogi ołtarza całopaleń i ołtarza kadzenia symbolizujące obecność Boga, u którego azyl może znaleźć nawet zabójca, i uchwyciwszy się rogów ołtarza - uzyskać ułaskawienie. Niektóre teksty używają terminu „róg” w znaczeniu naczynia na oliwę służącą do namaszczenia ludzi wybranych do pełnienia ważnych funkcji w Izraelu. Osoba namaszczona stawała się pomazańcem Pańskim. Mogła wtedy spełniać funkcję króla, kapłana lub proroka. Funkcje te wypełniała w imieniu Boga Jahwe. „Róg” może oznaczać też wkroczenie wielkiej Bożej mocy. Tak było w przypadku zdobywania Jerycha, gdy naród głośno zakrzyknął, a kapłani zagrali na rogach. Opis zdobycia murów Jerycha ma znaczenie teologiczne. Boża moc sprawiła rozsypanie się murów warownego miasta. Obraz procesji i dęcia w rogi został sformułowany przez redaktora kapłańskiego i podkreśla znaczenie kultyczne opisanych obrzędów. Istotne znaczenie posiada użycie terminu „róg” w pieśni Anny w 1 Sm 2, 1. 10. Tworzy on inkluzję obejmującą ten kantyk. Na początku pieśni słowa „róg mój” można odczytać w znaczeniu męskiego potomka Anny - Samuela, zaś na końcu jest mowa o „rogu mesjasza”. To właśnie Samuel namaścił Dawida na króla, którego potomkiem w sensie prorockim będzie obiecany Mesjasz. Zachariasz opowiada o Nim przy obrzezaniu Jana Chrzciciela. Wciąż otwartą kwestią pozostaje

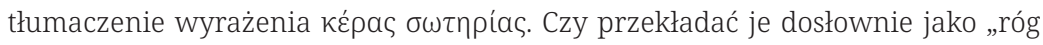
zbawienia”, czy raczej jako „moc zbawczą”? Wydaje się, że dosłowne tłumaczenie jest bogatsze w treść i daje głębsze zrozumienie przekazywanych prawd. W literaturze apokaliptycznej termin „róg” symbolizuje różne złe moce, które występują przeciwko Bogu i człowiekowi. Niektóre wystąpienia terminu „róg” symbolizują walkę władców ziemskich z ludem Bożym, a nawet z samym Bogiem. Apokaliptyka jednak pokazuje, że w końcowej walce zawsze zwycięża Bóg, który przewyższa swą mocą siły zła.

Słowa kluczowe: oliwa, ołtarz, róg, szofar, zbawienie 


\section{Abstract}

\section{Occurrences and meanings of the term "horn" in the Bible}

The "horn" in the Scripture literally means the horn of an animal and expresses its strength and power. The same term in the Old Testament describes the horns of the altar of burnt offering and the altar of incense, symbolizing the presence of God, from whom any murderer can find asylum and, taking hold of the horns of the altars, receive pardon. Some texts use the term "horn" to mean a vessel of oil used to anoint people chosen for important functions in Israel. The anointed one was becoming the Lord's anointed. He could then act as a king, priest or prophet and was performing these functions in the name of God Yahweh. The "horn" can also signify the entrance of great God's power. This was the case with the conquest of Jericho, when the people shouted loudly, and the priests played the horns. The description of the conquest of the walls of Jericho has theological significance. God's power caused the walls of the fortified city to fall completely. The image of the procession and the sound of the horns was formulated by the priestly redactor and emphasizes the cultic importance of the rites described. The use of the term "horn" in Anna's song in 1 Sam 2, 1.10 is significant. It creates an inclusion embracing this canticle. At the beginning of the song, the words "my horn" can be read to mean the male descendant of Anna, Samuel, and at the end of the song, the "messiah's horn" is mentioned. It was Samuel who anointed David to be King and whose offspring would be the promised Messiah in a prophetic sense. Zechariah tells about Him at the circumcision of John the Baptist. The translation of the ex-

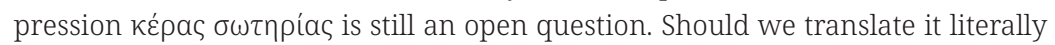
as a "horn of salvation", or as a "saving power"? The literal translation seems to be more significant and gives a deeper understanding of the communicated truth. In apocalyptic literature, the term "horn" symbolizes various evil powers that go against God and man. Some occurrences of the term "horn" symbolize the struggle of earthly rulers with God's people, and even with God Himself. The apocalyptic, however, shows that in the final struggle the God who surpasses the forces of evil, always wins.

Keywords: olive oil, altar, horn, shofar, salvation

\section{Bibliografia}

Albright, W. F., \& Cornelius, F. (1956). Die Religion Israels im Lichte der archäologischen Ausgrabungen. Ernst Reinhardt Verlag.

Auld, A. G. (2011). I \& II Samuel. A commentary. Westminster John Knox Press. 
Borowski, W. (1983). Psalmy. Komentarz biblijno-ascetyczny. Wydawnictwo Karmelitów Bosych.

Botterweck, G. J., \& Ringgren, E. (Eds.). (2004). Theological dictionary of the Old Testament. Volume 13: Qôs-raqîa’. William B. Eerdmans Publishing Company.

Brzegowy, T. (2010). Księga Izajasza. Cz. 1: Rozdziały 1-12. Edycja Świętego Pawła.

Eißfeldt, O. (1956). Einleitung in das Alte Testament: Unter Einschluss der Apokryphen und Pseudepigraphen sowie der apokryphen- und pseudepigraphenartigen Qumrän-Schriften. Mohr.

Galling, K. (1925). Der Altar in den Kulturen des alten Orients. Karl Curtius.

Gressmann, H. (1908). Die Ausgrabungen in Palästina und das Alte Testament. Mohr.

Jankowski, A. (Ed.). (1959). Apokalipsa świętego Jana. Wstęp, przekład z oryginału, komentarz. Pallotinum.

Kobielus, S. (2002). Bestiarium chrześcijańskie. Zwierzęta $w$ symbolice i interpretacji. Starożytność i średniowiecze. Pax.

Köhler, L., Baumgartner, W., \& Stamm, J. J. (2008). Wielki słownik hebrajsko-polski i aramejsko-polski Starego Testamentu. T. 1: Stownik hebrajsko-polski A-’ (P. Dec, Ed.). Oficyna Wydawnicza Vocatio.

Kraus, H.-J. (1958). Biblischer Kommentar, Altes Testament. XV.1: Psalmen. Neukirchener Verlag.

Łach, J. (1961). Pieśń Anny, matki Samuela (I Sm 2, 1-10). Ruch Biblijny i Liturgiczny, 14(3-4), 104-109. https://doi.org/10.21906/rbl.2815

Łach, J. (Ed.). (1973). Księgi Samuela. Wstęp, przekład z oryginatu, komentarz, ekskursy. Pallottinum.

Łach, J. B. (Ed.). (2007). Księgi 1-2 Królów. Wstęp, przekład z oryginału, komentarz, ekskursy. Pallottinum.

Łach, S. (Ed.). (1962). Księga Rodzaju. Wstęp, przekład z oryginału, komentarz. Pallottinum. Lemański, J. (2008). Księga Wyjścia. Wstęp, przekład z oryginału, komentarz. Edycja Świętego Pawła.

Meer, M. N. V. D. (2009). “Sound The Trumpet!” Redaction And Reception Of Joshua 6:2-25. In J. T. A. G. M. van Ruiten \& C. de Vos (Eds.), The Land of Israel in Bible, History, and Theology (pp. 19-43). Brill. https://doi.org/10.1163/ej.9789004175150.i-474.13

Mickiewicz, F. (2011). Ewangelia według św. Eukasza. Cz. 1: Rozdziały 1-11. Edycja Świętego Pawła.

Nelson, R. D. (2002). Deuteronomy. A commentary (1st ed.). Westminster John Knox Press. Parchem, M. (2008). Księga Daniela. Wstęp, przekład z oryginału, komentarz. Edycja Świętego Pawła.

Schwarzenbach, A. W. (1954). Die geographische Terminologie im Hebräischen des Alten Testamentes. Brill.

Tronina, A. (2006). Księga Kapłańska. Edycja Świętego Pawła. 
Vanni, U. (2009). Apocalisse: Libro della Rivelazione. Esegesi biblico-teologica e implicazioni pastorali. EDB.

Vaux, R. de. (2004). Instytucje Starego Testamentu (T. Brzegowy, Trans.). Pallottinum.

Würthwein, E. (1977). Das erste Buch der Könige. Kapitel 1-16. Vandenhoeck \& Ruprecht. 